\title{
7. QUATERNARY DINOFLAGELLATE CYST DISTRIBUTION AT SITE 820, GREAT BARRIER REEF ${ }^{1}$
}

\author{
Andrew McMinn²
}

\begin{abstract}
Compared with other Australian marine Quaternary locations. Site 820 's dinoflagellate cyst assemblages are low in both abundance and diversity. Abundances are between $<1$ and $14 \mathrm{cysts} / \mathrm{cm}^{3}$, and the number of species is between 7 and 14 per sample. The dominant species are Operculodinium israelianum, Spiniferites bulloideus, Spiniferites hyperacanthus and Tuberculodinium vancampoae, which together usually make up more than $75 \%$ of the assemblage.

The rareness of Protoperidinium spp., taxa usually associated with nutrient enrichment, suggests that upwelling was not a regular feature of this region during the Quaternary.

The relative dinoflagellate abundance, which indicates changes in the position of the coastline, shows the presence of several sea-level events, particularly near the base of the sequence. Here, they parallel at least two upward-coarsening cycles in the sediment record. Further comparison is hindered by too large a sampling interval.
\end{abstract}

\section{INTRODUCTION}

Site 820 is located on the Queensland continental slope in the Grafton Passage of the Great Barrier Reef in a water depth of $278 \mathrm{~m}$ (Fig. 1). The site contains a 400-m-thick, expanded Pleistocene sequence of wackestone, mudstone, and bioclastic packstone. The uppermost interval, Unit I (0-150.7 m), is composed of fine-grained wackestones and mudstones interbedded with bioclastic packstones. Unit II (150.7-208.1 m) is composed of a mixture of bioclastic packstones, bioclastic clayey mixed sediments, and silty claystones. Unit III $(208.1-400.0 \mathrm{~m})$ is dominated by bioclastic packstones with interbedded calcareous mudstones and mixed sediments. Pleistocene nannofossil assemblages from Zones CN15 to CN13b imply that the sequence is relatively complete. Planktonic foraminifers are limited to the upper Pleistocene Zones N22-N23 (Davies, McKenzie, PalmerJulson, et al., 1991). Preliminary ${ }^{18} \mathrm{O}$ analysis of the upper $135 \mathrm{~m}$ (this volume) has recognized the first 22 isotope stages, with the lowest of these being approximately equivalent to $800,000 \mathrm{yr}$. Fossil evidence for the age of the oldest sediments in the hole suggests a date between 1.27 and 1.48 Ma (Davies, McKenzie, Palmer-Julson, et al., 1991). Sedimentation rates vary from a high of $41.1 \mathrm{~cm} / \mathrm{k} . \mathrm{y}$. in the middle Pleistocene to more moderate rates of $8.2 \mathrm{~cm} / \mathrm{k}$.y. in the latest middle Pleistocene and $10-11 \mathrm{~cm} / \mathrm{k} . \mathrm{y}$. in the latest Pleistocene.

Most Quaternary dinoflagellate cyst studies are based on material from the Northern Hemisphere temperate and boreal zones. Australian studies, which are also mostly of temperate areas, include those of McMinn (1988, 1989, 1990, 1991a, 1991b, 1992b, 1992c) and Bint (1988). Only the studies of Wall et al. (1977) from the Caribbean, Bradford and Wall (1984) from the Persian Gulf, and McMinn (1992a) from the Timor Sea deal with tropical assemblages.

\section{METHODS AND MATERIALS}

Thirty-eight samples, approximately one per core, were collected by Leg 133 shipboard scientists for this study. All samples were processed at the palynological laboratory of the N.S.W. Geological Survey. Samples were initially disaggregated in $30 \% \mathrm{HCl}$, and then left overnight in $30 \%$ HF. After repeated washings in distilled water,

\footnotetext{
'McKenzie, J.A., Davies, P.J., Palmer-Julson, A., et al., 1993. Proc, ODP, Sci. Results, 133: College Station, TX (Ocean Drilling Program).

${ }^{2}$ Antarctic CRC and Institute of Antarctic and Southern Ocean Studies, University of Tasmania, Hobart, Box 252C. Tasmania 7001, Australia.
}

they were sieved on an $8 \mu \mathrm{m}$ screen with the aid of an ultrasonic needle. The residue was then further concentrated with the heavy liquid $\mathrm{ZnBr}_{2}$ solution, which had a 2.1 specific gravity. Neither oxidation nor $\mathrm{KOH}$ was used in the preparation. Residues were mounted in Eukitt and are stored in the Paleoecology Collection of the Institute of Antarctic and Southern Ocean Studies at the University of Tasmania, Hobart, Australia. All photography was done using a Zeiss Photomicroscope II at the N.S.W. Geological Survey, Sydney, Australia.

\section{COMPOSITION OF ASSEMBLAGES}

In comparison with Quaternary sequences from other areas, the abundance of dinoflagellate cysts at Site 820 is low (Table 1). Abundances are between $<1$ and $14 \mathrm{cysts} / \mathrm{cm}^{3}$, which compares with values of approximately 100 cysts/g on the N.S.W. continental shelf (McMinn, $1992 \mathrm{~b}$ ) and values of up to 20,000 cysts/g in some N.S.W. estuaries (McMinn, 1991b). These abundances also are significantly lower than those recorded from Neogene sequences of the Great Barrier Reef area (McMinn, this volume).

Species diversity is also low, with the number of species present varying from only 1 to 14 , with an average of 7 . The dominant dinoflagellate cyst taxa are Operculodinium israelianum, Spiniferites bulloideus, Spiniferites hyperacanthus and Tuberculodinium vancampoae, which together make up more than $75 \%$ of most assemblages. Protoperidinium, a genus often characteristic of areas of upwelling and nutrient enrichment and which is also common on the inner continental shelf in areas such as southeastern Australia (McMinn, 1992b), is present in less than $10 \%$ of the assemblages at Site 820 . However, Impagidinium, a genus typically associated with outer-shelf, slope, and oceanic-basin environments is present in more than half of the assemblages. Nematosphaeropsis lemniscata, another taxa associated with outer-shelf and oceanic environments, is less common and is found in less than $10 \%$ of the assemblages.

\section{ENVIRONMENTAL IMPLICATIONS}

The tropical location of Site 820 makes it difficult to interpret climatic cycles from the paleontological data, because water temperatures never became cold enough for the entry of cooler water taxa. Similarly, the site's outer-shelf location in a water depth of $278 \mathrm{~m}$ limits the amount of faunal and floral changes with changing sea level. Changes that did occur in the dinoflagellate assemblage composition are difficult to interpret and do not seem to be directly associated with either cooler or shallower water. At Site 820 little systematic change 


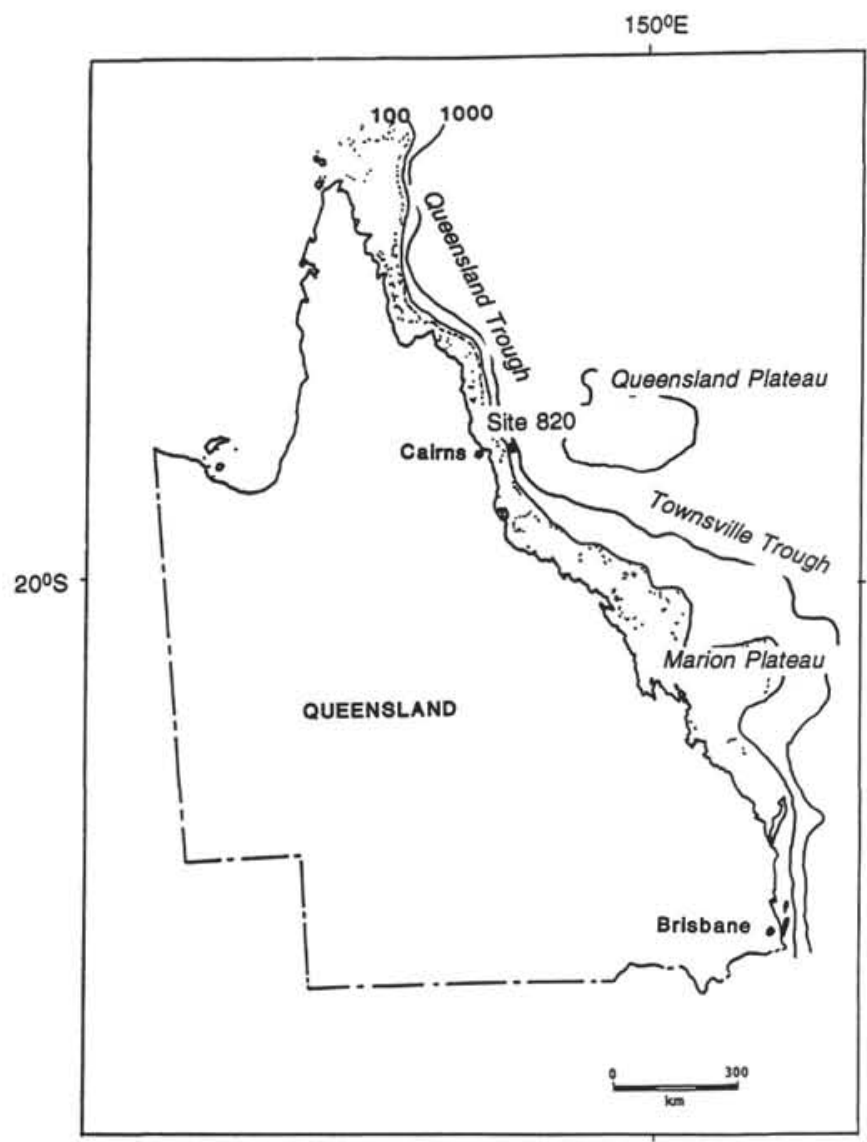

Figure 1. Location of Site 820 . Bathymetry in meters.

was seen in the relative dinoflagellate abundance with the changing abundance of the oceanic species Impagidinium spp. and Nematosphaeridium lemniscata. These species, which have been shown to reflect the changing position of the shoreline in southeastern Australia (McMinn, 1992b), were not abundant enough at Site 820 to provide a coherent picture of changes in sea level.

Although cysts of Protoperidinium spp. are sometimes abundant in estuarine and marine sediments, very high concentrations usually have been associated with nutrient enrichment (McMinn, 1992b). Uniformly low abundances at Site 820 during the Quaternary suggest that the Great Barrier Reef area has rarely been a site of nutrient enrichment. This contrasts with modern areas of known upwelling off the coast of Peru (Wall et al., 1977) and Indonesia (Van Waveren, 1989), where Protoperidinium abundances are high. As nutrient upwelling also is often associated with the strength of a current, the unchanging abundance of Protoperidinium at Site 820 may imply that the East Australia Current did not vary significantly in volume or velocity during the Quaternary.
Relative dinoflagellate abundance (i.e., the number of dinoflagellate cysts in a dinoflagellate plus pollen palynological assemblage) has been shown to reflect changing proximity of the coastline and thus indirectly reflect changes in sea level and possibly also climatic changes (McMinn, 1992b). In the lower part of the sequence at Site 820 (Samples 133-820B-44X-2, 74-77 cm, to 133-820B-28X-3, 70$74 \mathrm{~cm}$ ), two cycles representing rapid increases followed by a gradual decrease in sea level can be observed. These are indicated by high relative dinoflagellate abundances, which subsequently decline gradually. Several less well-defined cycles possibly overlie these lower two cycles. Closer sampling may provide more detail about changing sea level during this period.

\section{REFERENCES}

Bint, A.N., 1988. Recent dinoflagellate cysts from Mermaid Sound, northwestern Australia. Mem. Assoc. Australas. Palaeontol., 5:329-341.

Bradford, M.R., and Wall, D.A., 1984. The distribution of Recent organicwalled dinoflagellate cysts in the Persian Gulf, Gulf of Oman, and northwestern Arabian Sea. Palaeontographica B, 192:1-84.

Davies, P.J., McKenzie, J.A., Palmer-Julson, A., et al., 1991. Proc. ODP, Init. Repts., 133: College Station, TX (Ocean Drilling Program).

McMinn, A., 1988. A Late Pleistocene dinoflagellate assemblage from Bulahdelah, N.S.W. Proc. Linn. Soc. N.S.W., 109:175-181.

, 1989. Late Pleistocene dinoflagellates from Botany Bay, N.S.W. Micropaleontology, 35:1-9.

, 1990. Distribution of dinoflagellate cysts in estuarine deposits from the east coast of Australia. Proc 7th Int. Palynol. Congr., Rev. Palynol. Palaeobot., 65:305-309.

, 1991a. Quaternary dinoflagellate cyst distribution in Lake Macquarie. Q. Notes N.S.W. Geol. Surv., 85:1-6.

- 1991b. Recent dinoflagellate cysts from estuaries on the central coast of New South Wales, Australia. Micropalaeontology, 37:269-287.

, 1992a. Neogene dinoflagellate distribution in the eastern Indian Ocean from Leg 123, Site 765. In Gradstein, F.M., Ludden, J.N., et al., Proc. ODP, Sci. Results, 123: College Station, TX (Ocean Drilling Program), 429-441.

1992b. Quaternary dinoflagellate cyst distribution on the continental shelf and slope of southeastern Australia. Palynology. 16:13-26.

, 1992c. A late Pleistocene dinoflagellate and pollen record from the Richmond River Valley, northern N.S.W.; implications for the rate of sea level rise and climatic change. Quat. Res. 38:347-358.

Van Waveren, I.M., 1989. Protoperidinium cysts concentration in Recent to sub-Recent sediments of the Banda Sea responding to upwelling (Indonesia). Fourth Int. Conf. Modern and Fossil Dinoflagellates, Marine Biological Laboratory, Woods Hole, MA, 101.

Wall, D., Dale, B., Lohmann, G.P., and Smith, W.K., 1977. The environmental and climatic distribution of dinoflagellate cysts in modern marine sediments from regions in the North and South Atlantic Oceans and adjacent seas. Mar. Micropaleontol., 2:121-200.

\footnotetext{
Abbreviations for names of organizations and publications in ODP reference lists follow the style given in Chemical Abstracts Service Source Index (published by American Chemical Society).
}

Date of initial receipt: 20 April 1992

Date of acceptance: 3 December 1992

Ms 133SR-220 


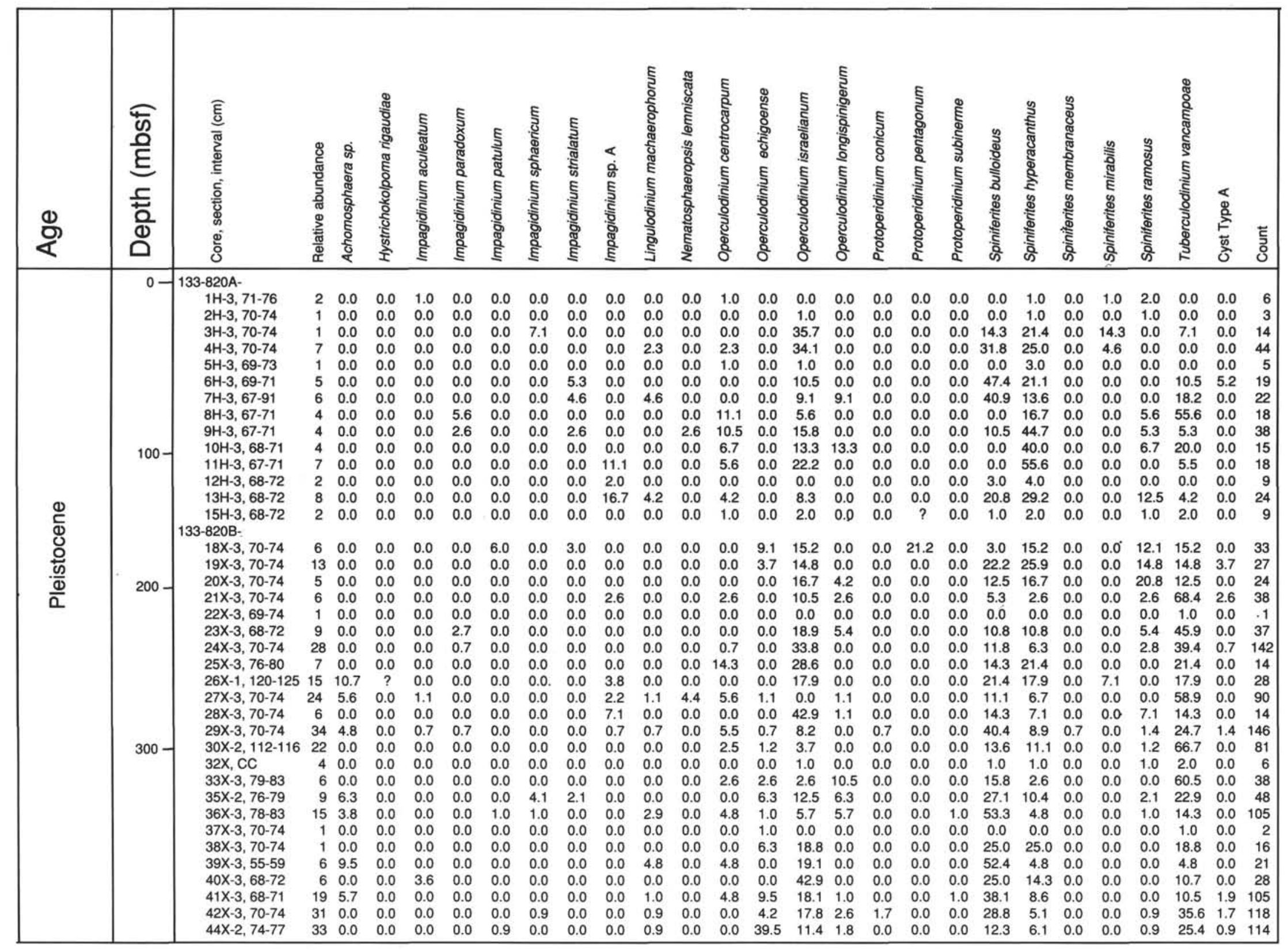

